\title{
The Research on the Paths of Hubei Higher Vocational Colleges' Serving the Regional Economic and Social Development
}

\author{
Hui Li ${ }^{*}$, Ping Li ${ }^{2}$, Lei Pei ${ }^{1}$ \\ ${ }^{1}$ Department of Finance and Economics, Wuhan City Vocational College, Wuhan, China \\ ${ }^{2}$ School of Economics and Management, Huazhong University of Science and Technology Wuchang Branch, \\ Wuhan, China \\ Email: ${ }^{*}$ 15377015817@163.com
}

Received 28 February 2015; accepted 16 March 2015; published 19 March 2015

Copyright (C) 2015 by authors and Scientific Research Publishing Inc.

This work is licensed under the Creative Commons Attribution International License (CC BY). http://creativecommons.org/licenses/by/4.0/

(c) (i) Open Access

\begin{abstract}
Higher vocational education is a mode of modern education, which can serve regional economy. Higher vocational colleges in Hubei have played a positive role in the service of economic and social development in the region, but from the point of higher vocational colleges themselves, there also exist problems as follows: some higher vocational colleges are unable to meet the diverse needs of talents because of the so-called popular majors; specialties setting of higher vocational colleges lack forward-looking, which is out of touch with the needs of the society; some higher vocational colleges cannot serve the society well; technology research and development of higher vocational colleges cannot satisfy social demand; talented teachers are not enough in higher vocational colleges. Our paper proposes that Hubei higher vocational colleges should take measures as follows: first, we should establish the education view of running the school open to cultivate applied talents to serve the development of regional economy and we should establish the programs according to the regional industry posts; second, we should make full use of teachers to provide consulting service for local government and enterprises; third, we should make use of resources to provide training and service for the society and expand the social service sphere; finally, we should make the occupation education concept merge into the regional members of society life.
\end{abstract}

\section{Keywords}

Higher Vocational Colleges, Service, Regional Economic and Social Development, Paths

${ }^{*}$ Corresponding author. 


\section{Introduction}

Higher vocational colleges should serve the regional economic and social development. It is not only the objective requirement of regional economic and social development but also the key factor which will affect the development of higher vocational colleges. Under the new situation, how to give full play to advantages of higher vocational colleges to promote the sound and rapid economic and social development of Hubei province, which is an important topic that has far-reaching historical significance and practical importance. The paper is organized as follows: The definition of regional economy is discussed in Section 2. Location of vocational education of Hubei higher vocational colleges is discussed in Section 3. Problems that higher vocational colleges in Hubei may be faced when serving regional economic and social development are discussed in Section 4. Suggestions for Hubei higher vocational colleges as for serving the regional economic and social development are discussed in Section 5.

\section{The Definition of Regional Economy}

Regional economy refers to a complex production caused by economic development in a certain region on the basis of internal factors and external conditions. The range can be big or small, therefore, the explanation for "regional" is numerous, common region is defined in accordance with the geographical scope, the administrative jurisdiction or the national common features, wherein the division method of geographic range, the national common feature is fuzzy, therefore, this paper will define the region as the administrative for higher vocational colleges area. As our study focuses on Hubei higher vocational colleges, the service range of regional economic development is for Hubei province.

\section{Location of Vocational Education of Hubei Higher Vocational College}

China's higher schools include four classes such as research university, teaching and research university, teaching colleges and higher occupation college. The higher occupation education is an important part of higher education, which shows more flexibility and highlight s the characteristics of service for local place, closely connected with the local economy. Hubei province is a large province which is outstanding as for education, however, from the level of economic development, Hubei province ranks among the top in the central region, but the provincial economic ranks, all the year round in the second echelon. The high-qualified education and teaching resources have trained a large number of outstanding talents, but how to make those talents promote the economic development of human capital is the urgent problem of higher education in Hubei. As for the comprehensive foundation and research ability, higher vocational colleges have no advantages, therefore, Hubei higher vocational education should closely connect with local economic construction, and make full use of the higher vocational colleges teaching facilities to provide training and guidance necessary for social construction.

\section{Problems That Higher Vocational Colleges in Hubei May Be Faced When Serving Regional Economic Development}

\subsection{Most Higher Vocational Colleges Are Unable to Meet the Diverse Needs of Society}

The higher occupation colleges have made vigorous developments in recent ten years; differentiation is not obvious among schools because school characteristics are not obvious. The school is often setting majors according to the market demand, but after the construction of the popular professional pursue, schools tend to fall into similar embarrassment. However, the social demand for professional and talent is diverse and extensive, our society not only needs popular professional talents, also needs less professional talents, therefore, the development of convergence in Hubei Province will hinder the diversified industry.

\subsection{Specialties Setting of Higher Vocational Colleges Lack Forward-Looking, Which Is out of Touch with the Needs of the Society}

At present, many higher vocational colleges have not realized the significance of serving social work. As for specialties setting, they do not take market needs into consideration, therefore, curriculum cannot adapt to regional economic structure. The employment situation of the so-called popular majors is not ideal, but a lot of professional talents related to regional economic development are not enough. According to the Twelfth Five- 
Year Plan Investigation Report, the number of high-skilled talents will reach 2 million in 2015 and reach 2.5 million in 2020. As shown in Table 1 and Table 2 for the "Twelfth Five-Year Plan", majors towards industries such as textile, food, energy saving and environmental protection, new energy are insufficient to meet the needs of society and majors towards new materials industry are almost blank (Fu \& Sheng, 2011).

\subsection{Talents of Higher Vocational Colleges Cannot Serve Society Well}

The first priority of higher occupation colleges is to cultivate students, but it is not the only mission of higher occupation colleges. In recent years, the employment situation of students in higher occupation college is good, therefore, higher occupation college have enough students, which makes the rapid development of vocational colleges. However, to regard "train students" as school functions cannot achieve the true sense of the regional economic development, vocational education ideas need to be expanded. On the other hand, we often face the embarrassment that we have sufficient graduates but we still could not meet the needs of society thus we have employment dilemma.

\subsection{Technology Research and Development of Higher Vocational Colleges Cannot Satisfy Social Demand}

At present, most of Hubei higher vocational colleges pay attention to cooperating with enterprises and are devoted to joint research and innovation but there still exist problems that research and development cannot satisfy social needs. It is common to see that pure scientific research output in previous years has increased such as scientific papers, awarded achievements, but the commercial application output such as the patent and new products are still low (Li, 2013).

\subsection{High-Qualified Teachers in Higher Vocational Colleges Are Not Enough}

As we all know high-qualified teachers are an important prerequisite for the development of schools, which also plays a key role in promoting the scientific research ability and serving ability of higher vocational colleges (Jin \& Xing, 2012). In contrast, most of the Hubei vocational colleges lack high-qualified teachers, which to some extent has affected and restricted higher vocational colleges' service for regional economic and social development. Only by continuously strengthening the construction of talent management team, creating a high-qualified teaching staff, can the society continues to transport all kinds of talents, to better serve the regional economic and social development.

Table 1. Curriculum provision of higher vocational colleges towards industries with 100 billion RMB production of Hubei Province.

\begin{tabular}{|c|c|c|c|c|c|}
\hline Industry & Revenue (100 million) & Ratio & Number of related majors & Students number & Ratio \\
\hline Steel & 2705 & $13 \%$ & 3 & 654 & $0.21 \%$ \\
\hline Petrochemical & 2443 & $11 \%$ & 3 & 1452 & $0.37 \%$ \\
\hline Food & 2342 & $11 \%$ & 4 & 1774 & $0.45 \%$ \\
\hline Textile & 1311 & $6 \%$ & 4 & 2196 & $0.56 \%$ \\
\hline
\end{tabular}

Table 2. Curriculum provision of higher vocational colleges towards parts of strategic new industries of Hubei Province.

\begin{tabular}{|c|c|c|c|c|}
\hline \multicolumn{2}{|c|}{ Industry } & Majors & Majors number & Students number \\
\hline \multirow[t]{2}{*}{$\begin{array}{l}\text { Energy saving and } \\
\text { environment protection }\end{array}$} & Environment protection & $\begin{array}{c}\text { Environmental Monitoring } \\
\text { Technology Environmental } \\
\text { Monitoring Technology and } \\
\text { evaluation }\end{array}$ & 7 & 387 \\
\hline & Energy saving & Energy-saving technology & 1 & 231 \\
\hline New energy & $\begin{array}{l}\text { Applied te } \\
\text { Generating electri }\end{array}$ & $\begin{array}{l}\text { ogy of new energy } \\
\text { echnology by new energy }\end{array}$ & 2 & 80 \\
\hline New material & 0 & 0 & 0 & 0 \\
\hline
\end{tabular}




\section{Suggestions for Hubei Higher Vocational Colleges as for Serving the Regional Economic and Social Development}

\subsection{To Change the Concept and Cultivate Applied Talents Who Can Adapt to the Development of Regional Economy}

On the one hand, the most important characteristic of higher vocational education is profession, namely the practical talents must serve the needs of the society. Undergraduate education tends to emphasize wide caliber, good foundation, and wide adaptation range, therefore students' comprehensive quality is high (Ding, 2013). The overall level of economic development in Hubei province is not high except Wuhan city whose economy is leading, scientific research and modern service development is good, all kinds of research and technical talents demand is relatively high while other municipalities in Hubei province are devoted to developing more traditional industries, which only needs skilled personnel. The higher occupation education should emphasize on helping students change the idea and let the students orient early and practice well to adapt to future work and new environment. On the other hand, the higher vocational colleges should fully understand the actual needs in the foundation of regional economic and social development on the adjustment of specialty setting, teaching content, the talent training scheme in order to meet the "five Hubei" construction and should pay attention to the development of strategic emerging industries and traditional pillar industry technical renovation of Hubei province in order to target training talents who can meet the needs of economic and social development of Hubei.

\subsection{Make Full Use of the Resources of Teachers in Order to Provide Consulting Service for the Local Government and Enterprises}

Compared with advanced universities, higher vocational colleges have more double-quality teachers. These excellent teachers have working experiences in the first line of each professional, who are familiar with the characteristics and trend of development of the industry and have strong professional research capacity in solving professional problems and can more quickly grasp the market and the society (Huo \& Ren, 2014). Therefore, the higher occupation education resources in Hubei province is not only confined to impart knowledge and educate people, these resources can be expanded to many fields of local area, for example, to participate in some of the projects of the government, provide policy recommendations, cooperate with enterprises, provide training for enterprises, participate in the project to help enterprises solve the problems. In these processes, the teachers of vocational colleges also can cooperate with the government and enterprises to create more practice opportunities for students.

\subsection{Make Full Use of Resources to Provide Vocational Training and Service for Society}

As we all know, the higher vocational colleges focus more on training practical skills of students and they are devoted to improving training conditions associated with market adaptation for students such as professional training room, laboratory, and experimental equipment. The higher occupation colleges should serve the local economic development (Research Team, 2010). For example, the higher occupation colleges can make full use of equipment of school to provide training for employees of local businesses. In this process, colleges can also negotiate with the corresponding enterprises, establish the cooperation relations and help students have part-time work in these enterprises. In addition, higher occupation colleges often have sufficient resources such as rich library, electronic information, and playground and so on; therefore these resources can be expanded for the society.

\subsection{Make the Concept of Vocational Education Merge into the Regional Members of Society}

"Live and learn" is a positive attitude towards life, when each social member is positive, the level of civilization of city will be greatly improved, and another way to serve the regional economy is to advance the city civilization (Sun, 2013). Vocational education should run through the life of the people, the higher vocational colleges can provide education environment for various stages of life, strengthen the ability to resist risk and uncertainty of the social members in order to achieve the true sense of the regional economic development. Higher vocational colleges can provide employment guidance and training for the unemployed and can also provide the necessary 
support for the professional interests of people. Through these processes, social value could be improved, the brand of the school will also promoted, which will make colleges better develop with regional economic development.

\section{Acknowledgements}

This work is supported by Humanities and social science projects of Hubei Province in 2014: Research on the problems and Countermeasures of Hubei higher vocational colleges serving the regional economic and social development [grant No. 14G587] and "Twelfth Five-Year Plan" key project of Wuhan Education and Science [grant No. 2013A041].

The authors also gratefully acknowledge helpful comments and suggestions of the reviewers, who have improved the presentation.

\section{References}

Ding, J.-C. (2013). The Situation Analysis and Route Choice of Higher Vocational Education Docking to the Regional Economy. Journal of Higher Education, 3, 61-66.

Fu, Y. Z., \& Sheng, F. Q. (2010). Research on the Situation, Problems and Measures of Hubei Universities Serving Economic and Social Development. Hubei Social Sciences, 6, 71-73.

Huo, R. G., \& Ren, L. J. (2014). The Situation Analysis and Route Choice of Higher Vocational Education in Hebei Province. Journal of Taiyuan Urban Vocational College, 12, 3-4.

Jin, L. J., \& Xing, H. X. (2012). Paths of Higher Vocational Education Serving Regional Economy. Modern Enterprise Education, 7, 44-45.

Li, H. (2013). Study on Vocational Colleges' Service for Economic Development of Hubei Province. Pioneering with Science \& Technology Monthly, 11, 116-117.

Research Team (2010). Status of Higher Vocational Education in Six Provinces in the Middle of China and the Development Countermeasures. Vocational and Technical Education, 28, 33-37.

Sun, X. Z. (2013). The Research on the Paths and Forms of Local Universities Serving the Regional Economic Social Development. M.E. Thesis, Xinxiang: Henan Normal University. 